\title{
Pengalaman Pasien yang Pernah Terpasang Ventilator
}

\author{
Yani AF Bastian, Suryani, Etika Emaliyawati \\ Fakultas Keperawatan Universitas Padjadjaran \\ Email:ynsuryani@yahoo.com
}

\begin{abstract}
Abstrak
Jumlah pasien kritis yang terpasang ventilator menempati dua per tiga dari seluruh pasien ICU di Indonesia. Kondisi kritis dengan terpasang ventilator akan menimbulkan masalah fisik, psikososial dan spiritual. Tenaga kesehatan terutama perawat perlu memberikan asuhan keperawatan terhadap pasien ICU yang terpasang ventilator secara menyeluruh. Penelitian kualitatif terhadap pasien yang terpasang ventilator sangat diperlukan sebagai upaya untuk menggali secara mendalam pengalaman hidup pasien selama terpasang ventilator dan menemukan new insight (pemahaman baru) tentang pengalaman mereka. Penelitian ini menggunakan metode kualitatif dengan pendekatan fenomenologi. Data didapatkan dengan wawancara mendalam terhadap 6 partisipan yang terdiri dari 2 laki-laki dan 4 perempuan, usia antara 27-54 tahun, yang terpasang ventilator antara 4 sampai 27 hari dan mendapatkan sedasi yang minimal. Analisis data menggunakan metode Colaizzi. Ada 8 tema yang didapatkan dari pengalaman hidup pasien selama terpasang ventilator yaitu (1) hilangnya harapan dalam menjalani hidup, (2) merasa telah diambang kematian, (3) prosedur suction yang dilematis antara nyaman dan tidaknyaman, (4) kehadiran orang terkasih sebagai spirit dalam melanjutkan hidup, (5) memandang penyakit sebagai rencana dari Tuhan, (6) memandang rendah citra diri, (7) pentingnya fasilitator dalam menjalani ritual keagamaan dan (8) keinginan untuk dirawat oleh tenaga kesehatan yang terampil. Individu yang hidup selama terpasang ventilator mengalami dilemma dengan prosedur suction, memiliki citra diri yang rendah, membutuhkan fasilitator dalam pemenuhan kebutuhan spiritual serta keinginan untuk dirawat oleh tenaga kesehatan yang terampil. Berkaitan dengan hal tersebut, pasien yang terpasang ventilator membutuhkan dukungan, pendampingan dan kemampuan yang terampil dari petugas kesehatan terutama dari perawat.
\end{abstract}

Kata kunci: Pasien kritis, pengalaman hidup, ventilator.

\section{The Experience of Patients after using Ventilator}

\begin{abstract}
The number of critically ill patients with mechanical ventilation occupies almost two-thirds of all ICU patients in Indonesia. The critical condition with mechanical ventilation will be followed by many human responses such as physical, psychosocial and spiritual problems. Health care providers, especially nurses are demanded to provide holistic care to the patients with mechanical ventilation. Qualitative study can be used to explore the life experience of the patients with mechanical ventilation to gain new insights of their experience. This study is a qualitative study using phenomenological approach. The data was obtained by in-depth interviews to six participants consisting of two men and four women with age range from 27 to 54 years. The length of time with mechanical ventilation was between 4 to 27 days and they received a minimal sedation. The data was analyzed by Colaizzi method of analysis. There were eight themes found from this study: hopelessness in life, feel closer to dying, the suction procedure dilemma between comfortable and uncomfortable, the presence of loved ones as a spirit for continuing live, the assumption of disease as God planning, perceived low self-image, the importance of the facilitator in religious rituals as well as the desire to be treated by skilled health care personnel. Patients with mechanical ventilation who experienced suction procedure dilemma have low self-image. They need a facilitator for meeting their spiritual needs, and caring from skilled health care provider especially from nurses.
\end{abstract}

Keywords: Life experience, mechanical ventilation, the critical Ill patient. 
Yani AF Bastian: Pengalaman Pasien yang Pernah Terpasang Ventilator

\section{Pendahuluan}

Penelitian ini dilatarbelakangi oleh pengalaman peneliti pada saat merawat pasien yang terpasang ventilator ketika peneliti menjalani praktek lapangan Keperawatan Kritis di ruang General Intensive Care Unit (GICU) salah satu rumah sakit di Bandung. Berdasarkan wawancara dengan beberapa pasien kritis yang terpasang ventilator, mereka memiliki masalah fisik, psikososial dan spiritual. Hal ini didukung oleh Samuelsson, 2006; Karlsson, Bergbom \& Forsberg 2012; bahwa pasien akan merasa nyeri, dan ketidaknyamanan yang disebabkan oleh tube endotrachea dan beberapa alat yang terpasang dalam tubuh pasien dan merasakan tidak berdaya.

Karena kompleknya masalah yang dialami oleh pasien yang terpasang ventilator seperti diuraikan di atas, tenaga kesehatan terutama perawat perlu memberikan asuhan keperawatan secara komprehensif. Pemahaman tentang kondisi dan kebutuhan pasien secara menyeluruh sangatlah penting dalam hal ini. . Di Indonesia sendiri, khususnya di Rumah Sakit yang berada di wilayah Jawa Barat, belum ada penelitian yang mengungkap pengalaman pasien selama terpasang ventilator. Di luar negri telah banyak dilakukan penelitian serupa yang dilakukan oleh Samuelsson (2006), Karlsson, Bergbom \& Forsberg (2012), dan Varga, Dioszeghy \& Frituz (2007). Atas pertimbangan bahwa adanya perbedaan latar belakang budaya, status sosial, perbedaan paham agama dalam hal melakukan ibadah dan proses perawatan yang dilakukan. peneliti tertarik untuk menggali pengalaman hidup pasien selama terpasang ventilator yang kemungkinan besar akan muncul pengalaman hidup yang berbeda dengan pasien di negara lain. Dengan ditemukannya hal baru (new insight) maka dapat meningkatkan pemahaman dan pengetahuan tentang masalah-masalah yang dialami oleh pasien yang terpasang ventilator, proses adaptasi yang dilakukan, dan kebutuhan apa saja yang diperlukan untuk memberikan perawatan. Dengan demikian, maka perawat dapat memberikan asuhan keperawatan secara holistik dan meningkatkan sikap caring pada pasien dengan kondisi kritis yang terpasang ventilator.

\section{Metode Penelitian}

Penelitian ini menggunakan jenis penelitian kualitatif dengan menggunakan pendekatan fenomenologi. Fenomenologi merupakan metode penelitian yang bertujuan untuk mengungkap live experiences tentang suatu fenomena (Suryani, Welch \& Cox 2013). Penelitian dilakukan terhadap 6 partisipan yang menggunakan teknik purposive. Kriteria inklusi untuk partisipan adalah Individu yang pernah terpasang ventilasi mekanik minimal 72 jam perawatan dan pernah dirawat di ruang GICU, mampu berkomunikasi dengan baik dan kooperatif, dan jarak ketika partisipan dilakukan pemasangan ventilator dengan waktu wawancara maksimal 6 bulan. Pengumpulan data dilakukan melalui wawancara mendalam (in-depth interview), dengan alat perekam suara menggunakan voice recorder, serta analisis data menggunakan metode Colaizzi 1978 (Wojar \& Swanson, 2007). Pada penelitian ini juga memperhatikan keandalan data dengan mempertimbangkan prinsip rigor dan trusworthiness dalam penelitian kualitatif serta prinsip - prinsip etika penelitian.

\section{Hasil Penelitian}

Penelitian ini, ditemukan delapan tema yang berdasarkan pada pengalaman partisipan yang pernah terpasang ventilator, yakni sebagai berikut :

1. Hilangnya Harapan dalam Menjalani Hidup

Rasa putus asa pada partisipan selama terpasang ventilator ditandai dengan ungkapan bahwa partisipan sudah ingin menyerah dan merasa tidak ada lagi harapan. Berikut yang diungkapkan partisipan:

“... bapa pernah merasa tidak punya harapan lagi, sepertinya tidak akan sembuh lagi, kalau melihat kondisnya seperti ini..."(P.2)

“....ada waktu-waktu nya aku pengen nyerah gituh " ya allah udahlah aku udah cape, dah 
Yani AF Bastian: Pengalaman Pasien yang Pernah Terpasang Ventilator

sok ambil gituh...”(P.5)

\section{Merasa telah Diambang Kematian}

Penelitian ini partisipan mengungkapkan seperti akan segera meninggal, kondisi ini terjadi ketika partisipan mengalami penurunan kesadaran. Berikut ungkapan partisipan :

“...udah nyampe mimpi didatengin almarhum bapa, ga tau kayaknya udah kepikiran mau dijemput.... udah gitu kayak dikasih satu buah gedung bukan gedung sih dikasih rumah tapi bagus banget rumah semuanya nya putih tapi ada gold nya rumah nya bagusbagus banget rumahnya gitu, tapi entah siapa gitu ada yg bilangin. Tapi Kamu belum boleh disini sekarang....." (P.5)

3. Prosedur Suction yang Dilematis - Antara Nyaman dan Tidak Nyaman

Hampir seluruh partisipan pada penelitian ini mengeluhkan rasa ketidaknyamanan berupa nyeri dan sesak yang diakibatkan oleh prosedur suction, akan tetapi partisipan tidak memungkiri bahwa meskipun menimbulkan nyeri dan sesak prosedur suction ini dapat membantu pemulihan kondisi partisipan. Berikut ungkapan partisipan:

“....yang namanya di suction di sedot kan, pertama pasti kerasanya cape, karena kan diambil oksigen ya disedot oksigennya.... Trus yang kedua pedih, sakit, iritasi....tapi kalo ga disuction kan ga enak penuh disini (tenggorokan) nya tuh...saya sendiri yang menderita.....'(P.5)

"... saya baru bisa tidur setelah di sedot..." (P.2)

4. Kehadiran Orang Terkasih sebagai Spirit dalam Melanjutkan Hidup

Penelitian ini, semua partisipan mendapatkan dukungan dari berbagai pihak, dukungan tersebut berupa dukungan moral, material dan sosial yang sangat bermanfaat bagi partisipan selama terpasang ventilator. Secara lebih spesifik dukungan yang didapatkan berupa kehadiran anggota keluarga baik itu dalam proses perawatan maupun ketika menjalani tindakan medis. Berikut ungkapan partisipan: “....pas mamah dateng nengokin disemangatin lagi... Liat foto anak oh iya semangat lagi..."(P.5)

“....Kalau yang lagi sakit kayak gini ya butuhnya diobrolin, harus banyak-banyak ngobrol sama pasien. Jadi diajak ngobrol ditungguin gitu ya, kayaknya dari demam juga jadi adem. siapa aja suster juga ga apaapa, jadi harus ada yang ngobrolin.. gini gini gini gitu, enak kalo ada yang ngobrolin mah...."(P.3)

5. Memandang Penyakit sebagai Rencana Dari Tuhan

Partisipan menganggap bahwa kondisi yang dialami selama terpasang ventilator merupakan cobaan dan musibah dari Tuhan yang harus mereka terima. Berikut ungkapan dari partisipan tersebut:

"..mungkin ini merupakan cobaan dari Allah, ya bagaiamana lagi harus diterima, mau bagaimana lagi ini sudah cobaan dari Nya..." (P.1)

\section{Memandang Rendah Citra Diri}

Penelitian ini, ditemukan adanya rasa malu pada salah satu partisipan dikarenakan dahak yang terus keluar dan prosedur suction yang sering dilakukan, yang berdampak pada harga diri yang rendah. Berikut ungkapan partisipan tersebut:

"... perasaan saya diruangan itu banyak yang sakit, tapi saya merasa paling menjijikkan karena dipasang yang seperti itu dan menimbulkan suara yang nyaring ketika mengeluarkan dahak sementara yang lain tidak....."(P.2)

Ket : yang seperti itu ; trakeostomi

7. Pentingnya Fasilitator dalam Menjalani Ritual Keagamaan,

Adanya perasaan sedih partisipan untuk dapat tetap melakukan ibadah sholat. Respon sedih sehubungan dengan ketidakmampuan melakukan ibadah sholat dan kebutuhan akan adanya bantuan untuk memenuhi kebutuhan spiritualnya diungkapkan oleh partisipan. Berikut yang diungkapan oleh partisipan: "... saya merasa sedih tidak bisa ingat antara siang dan malam, tidak ada yang memberitahu jadi kalau mau sholat juga bingung, bagaimana ini neng? Sebenarnya saya ingin ada yang memberitahu baik itu dari perawat atau dari siapa saja, kalau mau 
Yani AF Bastian: Pengalaman Pasien yang Pernah Terpasang Ventilator

sholat ingin dibantu, kalau di rumah sakit saya tidak bisa sholat jadi saya berdoa saja, tidak bisa sholat sama sekali berdoa saja..." (P.1).

“..melihat yang berbondong-bondong ke mushola itu ingin sekali ikut. Sayangnya ga bisa, keinginan nya besar tapi bagaimana saya tidak bisa, paling saya menangis, sedih. Padahal jarak ke mushola itu dekat...”(P.2).

8. Keinginan untuk Dirawat oleh Tenaga Kesehatan yang Terampil

Tema ini diangkat sesuai dengan pernyataan partisipan yang dengan jelas mengungkapkan bahwa kompetensi dan skill sangat penting dimiliki oleh tenaga medis. Berikut ungkapan partisipan tersebut :

"....biasanya yang pegang saya itu yang senior - senior jadi yang udah pada lama di ICU udah jadi tenaga ahli di ICU. Dan biasanya lama-lama mereka ngerti kemauan saya sendiri gitu. Kalo yang baru-baru kan saya nya udah ga bisa ngomong, pake ETT lagi, nanti dia-nya tindakannya salah lagi ga sesuai dengan pengennya saya akhirnya saya sebel sendiri kan...”(P.5).

Sebagai tenaga medis merupakan salah satu tugas perawat untuk menciptakan rasa nyaman baik itu karena prosedur tindakan, ataupun melalui lingkungan perawatan. Pada penelitian terdapat partisipan yang menyatakan merasa asing dan takut akan lingkungan perawatan sehingga membutuhkan infromasi dari tenaga kesehatan. Berikut ungkapan partisipan :

"....iya awalnya pengen ngelepas karena kita ga tau kita lagi dimana, ga tau lagi di ICU. rada kagok juga karena ngerasa ini teh mau diapain kok ini teh diginiin, kan dipincan yah aku teh....(P.3).

“...perasaan teh takut aja saya teh perasaan teh diruangan terus banyak orang ah ga tau lah.. teu pararuguh... pokoknya takut we, takut dijahatin apa kumaha gituh....'(P.4).

Selain itu seorang perawat yang terampil juga dituntut untuk memiliki kemampuan dalam memfasilitasi komunikasi pasien selain menggunakan media tulisan, yang dalam hal ini mengalami kesulitan. seperti yang diungkapkan oleh partisipan :
“... kalau sulit bicara suka difasilitasi alat tulis sama perawat, diminta untuk menulis tapi bagaimana tulisan nya tidak sesuai... "(P.1).

“...kalau mau komunikasi paling menulis, kalau ada perlu, ya menulis difasilitasi sama perawatnya.. ya Alhamdulillah meskipun kesulitan dipaksakan mau bagaimana daripada saya kesulitan kalau ada perlu, atau kalau mau minum, manggil memakai isyarat seperti memukul bed.."(P.2).

\section{Pembahasan}

1. Hilangnya Harapan dalam Menjalani Hidup

Terdapat ekspresi emosional yang ditunjukkan oleh beberapa partisipan dalam penelitian ini, yaitu merasa kehilangan harapan untuk sembuh dan dapat menjalani hidup dengan normal sebelum menjalani sakit. Kehilangan harapan atau putus asa yang dirasakan partisipan dikarenakan waktu perawatan yang lama dan merasa tidak mengalami perkembangan kesehatan, hal ini didukung oleh bahwa kondisi putus asa atau hilangnya harapan seseorang dapat disebabkan oleh kondisi yang statis dan kurangnya alternatif solusi (Kylma, 2005). Rasa tidak berdaya yang dirasakan oleh partisipan bisa menjadi salah satu pemicu hilangnya harapan untuk bangkit. Kehilangan harapan didukung oleh perasaan tidak berdaya yang merupakan salah satu indikasi dari pengalaman buruk selama pemasangan ventilator (Kim, Garvin, \& Moser, 2006). Dalam kondisi krisis seperti ini perawat harus mampu menguatkan harapan yang realistis kepada pasien terhadap kesembuhan nya akan tetapi tetap menginformasikan kemungkinan terburuk (Dworkind, 2010).

\section{Merasa Telah Diambang Kematian}

Pada keadaan kritis kondisi tubuh akan mengalami penurunan akibat gangguan fungsi organ vital seperti gangguan pernapasan, gangguan jantung serta organ vital lainnya (Price and Wilson, 2012). Pada penelitian ini partisipan mengungkapkan pengalamannya ketika berada dalam kondisi koma, dimana partisipan mengatakan pernah bermimpi 
Yani AF Bastian: Pengalaman Pasien yang Pernah Terpasang Ventilator

bertemu dengan anggota keluarga yang sudah meninggal dan seakan-akan telah mendekati kematian. Pernyataan ini didukung oleh Moorjani (2013) bahwa dalam kondisi kritis seseorang dapat merasakan tubuhnya terlepas dari jiwanya dan berada pada dimensi waktu yang berbeda. Dan pada umumnya mereka akan kembali ketika mendengarkan suarasuara atau semangat dari orang terdekat. Selain itu menurut Agustin (2012) pada pasien kritis yang terpasang ventilator, dapat merasakan hal-hal yang aneh diluar rasional seperti merasa dekat dengan kematian.

\section{Prosedur Suction yang dilematis - Antara} Nyaman dan Tidak Nyaman

Tindakan suction di area kritis pada dasarnya merupakan tindakan yang umum dilakukan terutama pada pasien yang terpasang ventilator, dengan melakukan intervensi tersebut diharapkan dapat memperbaiki jalan napas (Parekh, et al., 2011). Pada prinsipnya prosedur suction sangat bermanfaat untuk pasien. Hal ini seperti yang diungkapkan oleh pastisipan bahwa partisipan merasakan nyaman. Rasa nyaman yang dirasakan oleh partisipan didukung oleh penelitian Parekh et al. (2011) bahwa dengan dilakukan suction akan memperbaiki jalan napas pasien sehingga akan menimbulkan rasa nyaman. Selain merasakan keuntungan dan rasa nyaman dari prosedur suction beberapa partisipan juga mengungkapkan adanya nyeri. Pengisapan dilakukan hanya bila diindikasikan dan frekuensinya tidak ditentukan (Berman 2009). Selain itu prosedur suction dapat menimbulkan panik terutama jika itu pengalaman pertama, untuk mengurangi rasa panik sebaiknya perawat terlebih dahulu memberikan penjelasan prosedur setiap kali dilakukan (Karlsson, et al., 2011). Karena pada dasarnya perasaan panik saat prosedur suction dapat menimbulkan spasme pada saluran napas sehingga mengakibatkan sesak napas (Hudak \& Galo 2013). Keluhan ketidaknyamanan ini didukung oleh (Samuelsson, 2006, Karlsson et al., 2012, Varga, Dioszeghy \& Frituz, 2007) bahwa pasien yang terpasang ventilator merasakan ketidaknyamanan yang disebabkan suction dan beberapa alat yang terpasang dalam tubuh pasien.
4. Memaknai Penyakit sebagai Rencana dari Tuhan

Kondisi kritis dirawat di ICU dengan terpasang ventilator merupakan kondisi berat yang dapat mneyebabkan kematian. Hal ini akan menimbulkan stres pada penderitanya, akan tetapi hal ini dapat menjadi sarana untuk lebih memaknai kehidupan, dan memaknai kondisi yang dialami (Chao, Chen \& Yen. 2002). Dalam mencapai hal tersebut menurut Walton (2002) seseorang harus melewati fase yang panjang berubah-ubah dari waktu ke waktu, melalui pemaknaan spiritual tergantung dari tantangan yang dihadapi sampai pada tahap penerimaan. Selain itu jika dilihat dari sisi agama, dimana seluruh partisipan beragama islam, dan dalam pandangan islam bahwa sakit merupakan salah satu bentuk kasih sayang Allah agar menjadi lebih bersyukur, keyakinan tersebut termasuk salah satu faktor yang dapat mempercepat proses penerimaan terhadap kondisi yang dialami.

5. Kehadiran Orang Terkasih sebagai Spirit dalam Melanjutkan Hidup

Selama terpasang ventilator merupakan suatu kondisi kritis yang dialami oleh partisipan, yang tentunya dapat memengaruhi aspek fisik, psikologis dan spiritual. Kondisi ini membuat partisipan membutuhkan dukungan yang nyata dari berbagai sumber selama proses perawatan dan pemulihan. Keberhasilan pelayanan keperawatan bagi partisipan tidak terlepas dari peran keluarga. Hampir seluruh partisipan dalam penelitian ini mengungkapkan besarnya dukungan yang didapatkan darikeluarga, hal ini yang membuat partisipan menjadi lebih bersemangat untuk menjalani proses perawatan. Hal ini sesuai dengan yang dijelaskan Hudak \& Galo (2013) bahwa pada pasien yang tidak mampu berbicara atau tidak mungkin berkomunikasi verbal karena intubasi sangat memerlukan kehadiran keluarga untuk membantunya berkomunikasi. Hal ini didukung oleh penelitian kualitatif yang dilakukan oleh Lutter (2013) terkait pengalaman pasien kritis bahwa kehadiran keluarga sangat dibutuhkan oleh pasien, karena anggota keluarga dapat membangkitkan semangat pasien untuk sembuh, dan kehadiran keluarga merupakan dukungan yang nyata untuk pasien. Selain itu 
Yani AF Bastian: Pengalaman Pasien yang Pernah Terpasang Ventilator

kehadiran keluarga di samping tempat tidur partisipan dapat menurunkan kecemasan, meningkatkan dukungan sosial dan spiritual (Morton 2011). Disamping beberapa dampakdampak positif yang dipaparkan sebelumnya terkait pendampingan keluarga bagi pasien dalam hal ini kehadiran keluarga atau pengunjung pasien dapat menimbulkan efek negatrif terhadap pasien diantaranya dapat meningkatkan konsumsi oksigen pasien. Maka dari itu penting untuk dipertimbangkan mengenai kebijakan akan jadwal kunjungan pasien di ruang intensif terutama pada pasien yang terpasang ventilator dengan membatasi jumlah pengunjung akan tetapi tidak membatasi waktu kunjungan.

\section{Memandang Rendah Citra Diri}

Pada aspek psikologis muncul perubahan pada citra tubuh yang dialami oleh salah satu partisipan dalam penelitian ini, yakni adanya rasa malu dan merasa "jijik" terhadap kondisi yang dialaminya yang terus megeluarkan dahak dan menimbulkan bunyi yang nyaring dibandingkan dengan pasien yang lainnya. Dahak yang terus keluar disebabkan karena pemasangan trakeostomi yang memicu batuk dan produksi lendir yang berlebihan, hal ini yang dikeluhkan oleh partisipan. Rasa malu yang dirasakan partisipan diperkuat oleh penelitian Arabi dan Tavakol (2009) bahwa salah satu pengalaman yang dialami oleh pasien adanya perubahan pada citra diri. Dalam kondisi ini perawat memiliki tugas untuk menginformasikan kepada pasien bahwa kondisi yang dialami tidak akan berlangsung lama, seiring dengan membaiknya kesehatan pasien.

7. Pentingnya Fasilitator dalam Menjalani Ritual Keagamaan,

Pasien dengan kondisi kritis mengalami keterbatasan dalam menjalankan ritual keagamaan atau beribadah. Hal ini dialami oleh partisipan selama terpasang ventilator ketika menjalani perawatan di ruang ICU, terutama untuk melakukan ibadah sholat. Keterbatasan dalam menjalankan ibadah disebabkan adanya perasaan tidak berdaya karena kondisinya, dan ketidaktahuan akan waktu sholat. Maka penting bagi perawat untuk memberikan pendampingan dan memberikan bimbingan agar pasien tetap dapat melakukan ibadah. Hal ini didukung oleh penelitian Romdoni (2012) bahwa pasien ICU sangat membutuhkan adanya pendampingan dalam kebutuhan ibadah sholat salah satunya. Selain itu, menurut Wall, Engelberg, Gries, Glavan, \& Curtis (2007) tentang spiritual care pada pasien ICU bahwa $73 \%$ keluarga menyatakan perawatan spiritual dapat meningkatkan ketenangan dan kepuasan bagi pasien dan keluarga.

8. Keinginan untuk Dirawat oleh Tenaga Kesehatan yang Terampil

Seorang perawat yang bertugas di ruang intensif memiliki tiga tugas utama yaitu; life support, memonitor keadaan pasien dan perubahan akibat pengobatan dan mencegah komplikasi yang mungkin terjadi. Partisipan secara tidak langsung mengungkapkan keinginan dan kebutuhan akan perawat yang terampil dan memiliki keahlian yang baik, partisipan mengungkapkan rasa tenang ketika dirawat oleh perawat yang menurut mereka memiliki kompetensi dan mampu memenuhi kebutuhan nya. Pernyataan partisipan sesuai dengan hasil penelitian Emaliyawati (2011) bahwa pasien kondisi kitis menginginkan perawat yang tanggap dan sigap menangani keluhan. Tugas dan peran perawat tidak hanya berhenti dalam pemenuhan kebutuhan dasar, akan tetapi juga pemenuhan rasa aman, nyaman, dan pemberian informasi. Dalam penelitian ini didapatkan data bahwa partisipan mengungkapkan perasaan tidak nyaman akan lingkungan dan intervensi yang berhubungan dengan tidak diinformasikannya terlebih dahulu bagaimana kondisi lingkungan di ICU. Hal ini didukung dengan penelitian yang dilakukan oleh Thomas (2003) tentang manajemen klinik menghadapi stres pada pasien yang terpasang ventilator. Bahwa stresor pasien yang terpasang ventilator berupa fisik dan psikologis yaitu faktor lingkungan, komunikasi, kondisi kesehatan dan keefektifan intervensi. Hasil penelitian ini stresor yang pada umumnya muncul berupa sesak, cemas, takut dan nyeri. Maka dari itu untuk mengurangi rasa takut nya perawat bisa dengan memberikan informasi tentang kondisi partisipan dan orientasi lingkungan ketika partisipan berangsur 
Yani AF Bastian: Pengalaman Pasien yang Pernah Terpasang Ventilator

sadar untuk membiasakan klien dengan rutinitas ruangan yang serba cepat, atau bisa dilakukan ketika partisipan berada dalam kondisi tidak sadar. Pasien yang terpasang ventilator sangat membutuhkan informasi dan informasi tersebut didapat dari komunikasi yang efektif dengan perawat (Suryani, 2015). Seluruh partisipan mengungkapkan sulit komunikasi baik itu dengan tulisan sekalipun. Berdasarkan penelitian yang dilakukan oleh Guru, Suryani, dan Raharjo (2013) tentang analisis komunikasi pasien ICU, bahwa media gambar merupakan alat komunikasi yang efektif untuk digunakan pada pasien ICU yang terpasang ventilator

\section{Simpulan}

Pada penelitian ini ditemukan new insight yang tidak ditemukan dari hasil penelitian sebelumnya, Pertama adanya partisipan yang merasakan dilemma dengan prosedur suction yang dirasakan antara nyaman dan tidak nyaman. Selain itu munculnya pengalaman partisipan yang memimiliki citra diri rendah dikarenakan kondisinya, diamana merekan merasa "jijik" dengan dahak yang terus keluar. Selanjutnya bahwa selama terpasang ventilator individu mengalami distres spiritual dan keinginannya untuk difasilitasi dalam melakukan ibadah, serta adanya keinginan partisipan untuk dirawat oleh tenaga kesehatan yang terampil. Berkaitan dengan hal tersebut, pasien yang terpasang ventilator membutuhkan dukungan, pendampingan dari petugas kesehatan terutama dari perawat.

Hasil penelitian dapat dijadikan acuan bagi perawat dalam melakukan pengkajian kebutuhan asuhan keperawatan pada pasien yang terpasang ventilator, sehingga dapat dilakukan tindakan keperawatan yang cepat dan tepat terhadap pasien. Dengan demikian diharapkan dapat mendukung proses pemulihan yang cepat.

\section{Daftar Pustaka}

Agustin, W.R. (2012). Pengalaman pasien GBS (Guillain Bare Syndrome) pada saat kondisi kritis di Ruang GICU RSUP Dr. Hasan
Sadikin Bandung. Tesis Magister. Fakultas Keperawatan Universitas Padjadjaran.

Arabi. A., Tavakol. K. (2009). Patient's experiences of mechanical ventilation. International Journal Nursing Midwefery; 14(2): 83-88.

Berman, A. (2009). Buku Ajar Praktik Keperawatan Klinis, Kozier \& Erbs (edisi 5). Jakarta : EGC.

Chao, C.S., Chen, C.H \& Yen, M. (2002). The essence of spirituality of terminal ill patients. Journal of nursing research. 10(4): 237-245.

Dworkind, A, M (2010). Creating Hope in a Hopeless Situation : A communication manual for physicians offering quality at endof life care. Supportive care services: 1-19.

Emaliyawati, E. (2011). Kebutuhan Asuhan Keperawatan Klien Kondisi Terminal Infark Miokard Akut dan Keluarga Di Unit Rawat Inap IntensifRSHSBandung. (Tesis). Fakultas Keperawatan Universitas Padjadjaran.

Guru, Y, Suryani \& Raharjo. (2013). Analisis Kebutuhan Komunikasi pada Pasien Dengan Ventilasi Mekanik Selama Di Ruang GICU RSUP Dr. Hasan Sadikin Bandung. (Tesis). Fakultas Keperawatan Universitas Padjadjaran.

Hudak, C.M., \& Gallo, B.M. (2013). Keperawatan kritis : Pendekatan Holistik (Critical Care Nursing : A holistic Approach). (edisi 5 volume 1).Alih bahasa Allenidekania, B., Susanto, Nerera, \& Yasmin. Jakarta : EGC.

Karlsson, V., Bergbom, I., \& Forsberg, A. (2012). The lived experience of adult intensive care patients who were concoiuos during mechanical ventilation: A phenomenological. Harmeuneutic study. Intensive and critical care nursing, 28: 6-15.

Kim H, Garvin BJ, Moser DK. Stres during mechanical ventilation: benefit of having concrete objective information before cardiac surgery. American Journal of Critical Care 
Yani AF Bastian: Pengalaman Pasien yang Pernah Terpasang Ventilator

8(2): 118-26.

Kylma, J (2005). Dynamics of Hope in Adult Living with HIV/AIDS : a substantive theory. Journal of Advanced Nursing. 52 : 620-630. Lutler, L. R., Hayt, M., \& Ryan, T. (2013). A critical review and synthesis of qualitative research on patients experience of critical illness. Intensive and Critical Care Nursing, 29(3): 147-157.

Moorjani, A. (2013). Dying To Be Me books. Retrieved from http://astore.amazon.com/ newheavenneweart/detail/1401937519.

Morton, P.G., Fontaine, D., Hudak, C. M., \& Gallo, B. M. (2011). Keperawatan kritis: Pendekatan asuhan holistik (edisi 8); Alih bahasa: Nike Esti Wahyuningsih. Jakarta: EGC.

Parekh, D., Dancer, R. C., \& Thicket, D. R. (2011). Acute Lung Injury. Critical Care Medicine. 11(6); 615-618.

Price, S. A., \& Wilson, L.,M. (2012). Patofisologi-Konsep Klinis Proses-Proses Penyakit, (edisi 6). alih bahasa Nike Esti Wahyuningsih. Jakarta: EGC.

Romdoni, S. (2012). Pemenuhan Kebutuhan Spiritual oleh Perawat di Ruang GICU RSUP Hasan Sadikin Bandung. Tesis Magister Keperawatan Universitas Padjadjaran.

Samuelsson, K. (2006). Sedation during mechanical ventilation in intensive care: Sedation practices and patients 'memories, stresful experiences and psychological distres. (Doctoral dissertation). Department of Medical and Health Sciences, Lund University, Swedenn

Suryani. (2015). Komunikasi teurapeutik: Teori dan praktik. Jakarta : EGC.

Suryani, S., Welch, A., \& Cox. L (2013). The phenomena of auditory hallucination as described by Indonesian people living with schizophrenia. Archives of psychiatric nursing 27(6): 312-318.

Thomas, Loris A. (2003). Clinical Management of Stresors Perceived by Patients on Mechanical Ventilation. Advance Practice in Acute Critical Care Nursing, 14 (1): 73-81.

Walton, J. (2002). Finding A Balance: A Grounded theory Study of spirituality in hemodialysis patients. Nephrology Nursing Journal, 29(5): 447-457.

Wall, J. R., Engelberg, R, A., Gries, J. C., Glavan B., Curtis, R.J. (2007). Spritual care of families in the intensive care unit. Critical care medicine. 35(4) : 1084-1090.

Wojnar, D.M., \& Swanson, K (2007). Phenomenology: An Exploration. Journal Holistic Nursing, 25:172.. 